\title{
Gender, Poverty Elimination and Environmental Protection: Three Key Paths to Sustainable Rural Development
}

\author{
Reem A. Abuiyada ${ }^{1}$ \\ ${ }^{1}$ Department of Social Sciences, Dhofar University, Salalaha, Sultanate of Oman \\ Correspondence: Reem Abuiyada, Department of Social Sciences, Dhofar University, Salalaha, Sultanate of Oman.
}

Received: November 1, 2016

Accepted: November 16, 2016

Available online: November 17, 2016

doi:10.11114/ijsss.v5i1.1991

URL: http://dx.doi.org/10.11114/ijsss.v5i1.1991

\begin{abstract}
This paper argues that gender, poverty and the environment are three major challenges that have often been misunderstood or overlooked when planning for sustainable rural development. However, there is recently a growing awareness by international development planners, economists and policy makers that a focus on these three key challenges takes development, specifically rural development to a new level of or path to sustainability. The analysis of these three key challenges will help give appropriate consideration to the important role that should be played by 'determined and committed' rural people, both men and women, in promoting and developing their own livelihoods and environment to reach sustainable development in collaboration with other agents in the society.
\end{abstract}

Keywords: gender, poverty, sustainable, development, challenges

\section{Introduction}

Development thought in the 1950s and 1960s focused on increasing growth levels until the economy reaches a 'take-off' point into sustainable development. Economic growth in rural areas was viewed as a simple matter of applying appropriate levels of investment, using new technology and introducing new high yield varieties (HYV) of seeds. This approach would have a 'trickle down' effect that would eliminate rural poverty, ensure equity and improve the situation of women. The optimism of this era, however, could not be sustained. It appeared empirically that economic growth had increased poverty, widened the gap between the rich and the poor, reinforced women's subordination and increased environmental degradation as a result of overexploitation of natural resources and increased commercial use. The Green Revolution in India is one clear example that confirms this situation (Bernstein, et al., 1992). Another principal cause of the failure of this approach to development is the absence of grassroots participation, especially women's participation in rural areas. Thus, one could argue that this era had led to 'negative' development that was followed by the rise of the debt crisis.

The debt crisis of the 1980s coupled with climatic disasters such as droughts and civil wars, especially in Sub-Saharan Africa has tremendously increased poverty and particularly that of women. This has led to what has been termed by the United Nations Development Programme (UNDP) as the 'feminisation of poverty', reflecting in part the growing number of women-headed households (Akeroyd, 1991).

The introduction of the structural adjustment policies (SAPs) by the Bretton Woods institutions, the World Bank and the International Monetary Fund (IMF), in an attempt to solve the debt crisis and global recession, and reduce poverty have created more burdens on the poor, women and increased environmental degradation. SAPs have put emphasis on "improving economic management and allowing greater play for market forces" (World Bank, 2001).

The World Bank's World Development Report 1990 focusing on poverty reduction proposed a two-pronged strategy: promoting labour-intensive growth and a broad provision of social services mainly health and education. It argued that:

Countries that have been most successful in attacking poverty have encouraged a pattern of growth that makes efficient use of labour and have invested in the human capital of the poor. Both elements are essential. The first provides the poor with opportunities to use their most abundant asset-labour. The second improves their immediate well-being and increases their capacity to take advantage of the newly created possibilities. Together they can improve the lives of most of the world's poor (World Bank, 1990). Whereas some considerable achievements have taken place in some countries or regions within a country, destitution and inequality still persist (World Bank, 2001). In fact, SAPs have increased the vulnerability of women by not taking into account the 
different roles played by household members in the struggle to survive. Women have not been recognised for their contributions to the labour market, while bearing the brunt of childbearing and rearing family, healthcare and other community activities (Elson, 1992).

With regards to the environment, SAPs focus on the commoditisation of labour through the growth of wage employment outside the household has reduced 'the pool of unpaid household labour'. This has created what came to be referred to as the 'individualisation' of production and established 'opportunity cost', particularly for male labour. In turn, many traditional farming practices could not be applied, which led to soil degradation, malnutrition, and a reduced ability to travel distances to collect fuel wood, which has intensified the local exploitation of trees, deforestation and environmental degradation. The Millet Cultivation in Mali and the Sahel region is a striking example of the impact of the market forces on traditional farming practices and the environment (Bernstein, et al., 192).

All these challenges have made international development institutions, mainly the World Bank make its mandate the reduction of poverty, improving living standards, and protecting the environment through sustainable, broad-based growth and investment in 'people'. Sustainable rural development is now seen as a powerful contributor to achieving this mandate (World Bank, 1997). Thus, a shift has occurred by the start of the new century, where the World Bank has put much emphasis on reducing vulnerability and poverty by taking action into three areas: promoting opportunity, facilitating empowerment and enhancing security of the poor and vulnerable groups (World Bank, 2001).

This paper will focus on eliminating gender disparity, reducing poverty and protecting environmental resources as three-key challenges that need to be met to achieve sustainable development especially in rural areas. The achievement of sustainable rural development will depend mainly on the amount of co-operation and collaboration between the different agents in society—government, civil society, the private sector and the poor people themselves (World Bank, 2001).

\section{The Challenges}

\subsection{Gender}

Development planners and policy makers are becoming more aware of the nature and impact of gender, women's empowerment and their participation with men in shaping the decision-making process to improve rural livelihoods and reach sustainable development. Before embarking on a discussion of the importance of gender in achieving sustainable rural development and challenges facing the elimination of gender disparity and the full empowerment of women, it is important to start by defining the concept of gender, understanding gender needs and the different approaches to gender.

\subsubsection{Defining Gender}

Social scientists differentiate between 'sex' as a biological term that describes biological and physical differences between men and women, and 'gender' as a sociological term that describes these differences as being 'socially and culturally constructed'. These differences are reflected in: roles, responsibilities, access to resources, constraints, opportunities, needs and perceptions held by both sexes (Barnett, 1988; Foster-Carter, 1985).

Women have particular needs that differ from those of men, because of their usually subordinate position to men. There are two types of needs: practical and strategic. Practical needs include improving their health and services for their families, increasing their income and reducing their workload. Strategic needs, on the other hand, include improving their education opportunities, gaining equal opportunity for employment and ownership, and increasing their participation in decision making (Moser, 1993. Quoted in Pearson, 2000; Foster-Carter, 1985).

\subsubsection{Approaches to Gender}

It is interesting to note that a gender-based debate began to take shape in the 1970s by the publication of the Danish development analyst, Ester Boserup's book Women's Role in Economic Development. She "helped to put women and development into an international context by clarifying both the human dimension of economic development and the policy issues raised by the development projects undertaken in the 1960s" (Charlton, 1984).

From there on, many development agencies began to incorporate women's needs in their projects. The position of 'women in development' was also strengthened by having a UN Decade for Women (1975-1985), and holding many international conferences targeting women like the International Women's Conference in Nairobi (1985), and Beijing (1995), the International Conference on Population and Development (ICPD), Cairo 1994, and the Copenhagen Summit on Population and Social Development (1995), Habitat (1996).

During this period, many studies focusing on women and gender relations were undertaken. The Women in Development Office of the US Agency for International Development (WID/USAID) financed a wide variety of studies related to development, women and using appropriate technology for female farmers (Charlton, 1984). Different approaches to gender had been developed throughout this period. One approach that Boserup's work had contributed to 
is Women in Development (WID) focusing on addressing women's needs by integrating them into development projects (Charlton, 1984; Braidotti, et al., 1994). In the 1970s and onwards, there was also a growing interest in women's relations with the environment, which resulted in the emergence of the women, environment and sustainable development (WED) approach (Braidotti). With shifting focus to poverty alleviation and structural adjustment, in addition to the environment, in the 1980s, the approach was referred to as Gender and Development (GAD) emphasising on gender relations and treating policy interventions as requiring a gender analysis in order to assess their likely impact (Pearson).

One of the GAD variations is the well-known 'efficiency approach', which stresses the importance of active participation of women in projects to become effective and efficient. 'Empowerment' is another approach focusing on removing social and institutional barriers to reach structural change in gender relations as well as economic growth (World Bank, 2001). These approaches, especially empowerment, with its emphasis on structural change clarifies that gender has a very important role to play in the initiation and promotion of sustainable development, especially in rural areas.

\subsubsection{Why Gender}

The important question that should be asked now is why does gender have this important role, especially in sustainable rural development, and what is hindering it from having its full potential?

Throughout the world's rural areas, both men and women are heavily involved in agricultural production and other economic activities for household consumption and for sale. Women's role in agriculture differs greatly from one area to the other. In Sub-Saharan Africa, for example, rural women are responsible for 60-80 percent of the agricultural labour for food production, its storage, transport and sale. This is coupled with their other reproductive activities, like childbearing, rearing, preparing food, gathering fuel and water. Women could spend up to 16 hours a day doing these domestic and farm tasks.

Despite this tremendous effort, most of these rural women are not directly remunerated for their work or reap little benefit from their labour (Afsher, 1991; Moser, 1993). Focusing on rural women in Southern Africa (Zambia, Zimbabwe and Malawi) in relation to their access to and control of resources, Anne Akeroyd (1991) argues that although these women have de facto responsibilities as being female-heads of households, they lack de jure control over decision-making and the allocation of resources. For example, a married woman may need her husband's approval before buying items either for investment or consumption, undertaking paid work, or making gifts or loans to her kin.

Again, in India, rural women have restricted access to assets and other basic needs, especially in tribal areas and among the lowest castes in the social hierarchy (Bernstein, et al.). In Latin America, many rural women are also subjected to acute pressures and deprivation as a result of their proletarianisation in agro-industries. Other rural women, who become in full charge of their husbands' minifundias, who migrate for work in cities, are not remunerated for their work (ibid).

There are many gender discriminatory practices and inequalities exemplified in lower literacy rates of women, limited access to productive resources (e.g., land, credits, technology); social services (e.g., health, legal services); and limited power in the decision-making processes. Different interpretations were given to these discriminatory practices against women. One explanation by the reductionist approach limits it to physical differences. Other approaches focus on the political, cultural and ideological explanations (Barnett).

Politically speaking, women, have little or no formal institutionalised power at local, national or international levels. The greater their empowerment and involvement in non-domestic or public, the greater their status and influence (Charlton, 1984). This, however, should be coupled with an improvement of men's position and maintaining equilibrium between the power of both men and women to avoid potential conflict. The case of empowered women in rural Vietnam is a vivid example of how gender conflicts could arise by changing women's positions (White, 1987).

From a cultural and ideological point of view, Afsher (1991) argues that there are ideological misconceptions related to women's productive role that deny them the right to work and idealise their image as 'home-based, child-rearing women'. These misconceptions also aim at protecting their honour and dignity (Afsher, 1987). Development could take place "only if and when it addresses the double-burdens of production and reproduction carried by women" (Afsher, 191). Once women's productive roles are accepted, it becomes easier to begin the long process of ideological change, empower women and eliminate their subordination.

The slow process of integrating women into development and empowering them has led to the rise of a new strategy focusing on mainstreaming gender into development policies and programmes, i.e., "applying gender analysis to all aspects of development, rather than just to women or women's issues" (Pearson, 2000). Mainstreaming gender, however, is argued to be not enough as it only focuses on WID approach. "There is a need for a broader, critical (GAD) approach addressing strategic gender interests and analysing the causes of gender inequality. However, this should not be seen as a polarised debate since both approaches are needed" (ibid). There is another way of understanding 
'mainstreaming' that is to 'de-link' it from a WID or a GAD approach and include the role of men in any analysis or proposed solution to women's subordination (ibid). It is this last understanding of gender mainstreaming that could strongly help in reaching sustainable development.

\subsection{Poverty}

"Poverty is an age-old concern" (Thomas, 2000). It has now come to a state of being perceived as 'the world's greatest challenge'. Poverty is a multi-dimensional, multi-faceted complex phenomenon. It is "the result of economic, political and social [and cultural] processes that interact with each other and frequently reinforce each other in ways that exacerbate the deprivation in which poor people live" (World Bank, 2001). Reducing or eliminating poverty by economic development (within a pure capitalist framework) is not enough (Thomas, 2000). Eliminating poverty implies interventions at different levels to improve the well-being of poor people, especially in rural areas and ensure sustainability. But before discussing the different aspects of poverty and actions for improvement and sustainability, it is important to take an overview of the conceptions of poverty and its measurement.

\subsubsection{Conceptions and Measurement of Poverty}

First, it should be noted that poverty applies to the level of individuals, households and even entire nations on the basis of their gross national product (GNP). At the individual level, the World Bank established a 'poverty line', which represents an income level below which a person is held to be in extreme poverty, (i.e., having an income less than US $\$ 1$ per day measured in '1985 PPP dollars') (Thomas). According to the World Bank (2001), "of the world's 6 billion people, 2.8 billion - almost half-live on less than $\$ 2$ a day, and 1.2 billion - a fifth-live on less than $\$ 1$ a day, with 44 percent living in South Asia”. The majority of these people live in rural areas (Bernstein, et al., 1992).

Another indicator for measuring poverty, used by the World Bank, is the 'poverty gap' defined as "the aggregate or total income shortfall of the poor as a percentage of total (national) consumption" (Bernstein, et al.). Using this indicator also shows that South Asia and Sub-Saharan Africa, where the majority of the population is rural, have the most severe and widespread poverty. This measurement of poverty as lack of adequate income or assets to generate income that was used by the World Bank before the 1980s is not enough to explain poverty. There are other dimensions used. Relative poverty is among the most common ones. Developed by Townsend, it focuses on exclusion from "ordinary living patterns, customs and activities" (Townsend, 1979. Quoted in Thomas, 2000; Bernstein, et al.). Poverty was also seen as failure to take part in human society as a result of lack of 'endowment' and 'entitlement' rather than simply material living standards (Sen, 1981. Quoted in Allen \& Thomas, 2000).

A more comprehensive approach to measuring poverty was developed by David Morris known as the Physical Quality of Life Indicator (PQLI) based on three indicators: life expectancy, infant mortality and literacy rates. Based on this approach, the UNDP introduced the Human Development Index (HDI) in 1990, which combines life expectancy, educational attainment (encompassing mean years of schooling and adult literacy) and material standard of living (measured by GDP per capita in PPP dollars). Most recently, the UNDP introduced the Human Poverty Index (HPI) that has two different indices, one for developed industrialised countries, and one for developing countries (Thomas).

It is clear from all these various measures that the basic issue regarding poverty is the inability to satisfy basic needs and reach physiological efficiency. Thus, in its definition of poverty, the Copenhagen Declaration of the World Summit for Social Development (1995) stated that poverty is "a condition characterised by severe deprivation of basic human needs, including food, safe drinking water, sanitation facilities, health, shelter, education and information. It depends not only on income but also on access to services". This established view of poverty is recognised now by the World Bank. James Wolfensohn, The President of World Bank, in his foreward to the World Development Report (2000/2001): Attacking Poverty, defines poverty as "encompassing not only low income and consumption but also low achievement in education, health, nutrition and other areas of human development. And based on what people say poverty means to them, it expands this definition to include powerlessness and voicelessness, and vulnerability and fear" (World Bank, 2001, p.v).

\subsubsection{Different Aspects of Poverty}

From these new conceptions of poverty, one could deduce different aspects of poverty. They can be summarised as follows: need; low standard of living; limited resources; lack of basic security; lack of entitlement; multiple deprivation; exclusion; inequality; dependency; unacceptable hardships; powerlessness; and vulnerability.

\subsubsection{Actions for Poverty Reduction and Elimination}

The IMF, OECD, UN and World Bank (2000) have identified seven development goals that address different aspects of poverty. Achieving these goals by 2015 would reduce poverty and achieve sustainability. All the seven goals are strongly related to rural development. They are: (a) reduce the proportion of people living in extreme poverty by half; (b) enrol all children in primary school; (c) make progress toward gender equality and empowering women by eliminating gender disparities in primary and secondary education; (d) reduce infant child mortality rates by two-thirds; (e) reduce 
maternal mortality ratios by three-quarters; (f) provide access for all who need reproductive health services; (g) implement national strategies for sustainable development in every country by 2005 , so as to reverse the loss of environmental resources by 2015 (World Bank, 2001).

The World Bank also proposes action for attacking poverty in three parallel and complementary ways: promoting opportunity, facilitating empowerment and enhancing security. The first strategy implies providing the poor with jobs, credit, infrastructure assets and markets. This requires action by the nation-states and efforts to narrow the inequality gap between the haves and have-nots. The second strategy focuses on strengthening participation of poor people in the political processes and decision-making; removing institutional barriers; achieving access, good governance and accountability. This, however, requires collaboration between different sectors and agents in the society. The last strategy focuses on reducing vulnerability, improving livelihoods and enhancing well-being. It also requires building the assets of the poor and providing insurance mechanisms to cope with economic and natural shocks (World Bank, 2001).

\section{The Environment and Sustainability}

The third challenge discussed in this paper is protecting the environment as a means or path to reach sustainable rural development. The environment is, in fact, one of the most potent factors influencing development, and the security and survival of human beings. Concern with environment has started in the second half of the twentieth century, but has not reached its peak except in the 1980s with the setting up of the UN World Commission on Environment and Development (WCED), known as the Brundtland Commission, and the publication of its report in 1987. This report links the environment with the concept of sustainable development. The environment with its various natural assets or resources including renewable (ecosystems), non-renewable resources (fossil fuels), and the waste-assimilation capacities of ecosystems should meet "the needs of the present without compromising the ability of future generations to meet their own needs" (Woodhouse, 2000).

The discussion of environment in this section will focus on environmental degradation in non-industrialised economies, specifically rural areas and implications of managing natural resources as a path to reach sustainable rural development.

There is a misconception that the increasing poor rural population is the main cause of environmental degradation and depletion of natural resources, not because of their high levels of consumption, but because their poverty drives them to seek survival through unsustainable means that degrade these natural resources. However, there are various technical and social factors that cause environmental degradation other than population growth. One factor is livelihoods or economic activities of rural, non-industrial economies, which depend more on 'primary commodity production' closely linked to exports to industrialised countries. Falling prices of these primary commodities implied reduced income. To overcome this dilemma, governments had to borrow, increase production, and reduce the cost. This has depleted resources by overexploiting them and negatively affected the rural people's standard of living (Woodhouse, 2000).

Protecting the environment from degradation and managing natural resources/assets implies maintaining these assets intact or renewing them. However, as this is not easy because of the necessity of meeting the present needs and renewing the same resources, it was thought that having a free and open market policies, and finding technological substitutes for particular resources would ensure sustainability. But the market and prices alone cannot foster sustainability. The economy is not in isolation from the environment, it is rather an integrated and wholly dependent subsystem of the environment (Rees, 2001).

Attempts to protect the environment always come at the expense of the poor local inhabitants whose perspectives and priorities are marginalised, and with no positive effects. External authorities exert various forms of control over people and their resources, after compromising the villagers' resource management and attracting considerable animosity. This, however, does not hinder these people from finding other ways to secure their needs, which exacerbates the problem of environmental degradation. In many cases, people would refer to covert ways of fire selling or tree felling, or offering largesse to forest guards. This shows that money is the main priority, rather than any concern with forests and their protection (Fairhead \& Leach, 1997).

Another alternative to manage the environment is through enhancing the sustainability of the community or securing 'sustainable livelihoods' for the poorest groups within communities. However, there are doubts about the economic viability of this paradigm because of high dependence on world markets. A third alternative is the 'global environmental management', which implies co-operation at the global level through enforced international environmental treaties. 'Agenda 21', formulated and adopted at the 'Earth Summit' in Rio 1992, is an example of this view. The viability of this view depends on how far the concerned parties can negotiate their interests and the manner in which they participate in the global economy and the development process (Woodhouse). 


\section{Conclusion}

This paper tackled gender, poverty and the environment as three key challenges to achieving sustainable rural development. The relationship between these three challenges and sustainability is complex as all of them are closely interrelated. Tackling one challenge and neglecting the others would bring undesirable effects. To achieve sustainability, it is important to have good information and successful collaborative development planning that involves all stakeholders or agents in the society. These stakeholders, however, should have the determination and commitment to change and transform the existing system into an equitable and just sustainable system that promotes opportunity through programmes that extend equal access to land, credit and other services that satisfy basic human needs; facilitates empowerment and removes political, economic, social, cultural and ideological barriers resulting from distinctions of gender, class, etc; and enhances security of the poor and the vulnerable groups. This long-term sustainable action should be from above and from below to meet the desired objectives of development.

\section{References}

Afshar, H. (1991). Women, Development and Survival in the Third World. London: Longman.

Afsher, H. (Ed.). (1987). Women, State and Ideology: Studies from Africa and Asia. London: Macmillan Press. https://doi.org/10.1007/978-1-349-18650-1

Akeroyd, A. (1991). Gender, Food Production and Property Rights: Constraints on Women Farmers in Southern Africa, in Afsher, H. (ed). Women, Development and Survival in the Third World. London: Longman.

Barnett, T. (1988). Sociology and Development. London: Routledge.

Bernstein, H. et al. (Eds.). (1992). Rural Livelihoods: Crises and Responses. Oxford: Oxford University Press.

Braidotti, R. et al. (1994). Women, the Environment and Sustainable Development: Towards a Theoretical Synthesis. London: Zed Books.

Charlton, S. (1984). Women in Third World Development. London: Westview Press.

Elson, D. (1992). From Survival Strategies to Transformation Strategies: Women's Needs and Structural Adjustment, in Beneria, L. \& Feldman, S. (eds.). Unequal Burden: Economic Crises, Persistent Poverty, and Women's Work. Oxford: Westview Press.

Fairhead, J., \& Leach, M. (1997). Webs of Power and the Construction of Environmental Policy Problems: Forest Loss in Guinea, in Grillo, R. D. \& Stirrat, R. L. (eds.). Discourses of Development: Anthropological Perspectives. Oxford: Berg.

Foster-Carter, A. (1985). The Sociology of Development. Lancashire: Causeway Books.

Moser, C. (1993). Gender Planning and Development: Theory, Practice and Training. London: Routledge. https://doi.org/10.4324/9780203411940

Pearson, R. (2000). Rethinking Gender Matters in Development, in Allen, T. \& Thomas, A. (eds.). Poverty and Development into the $21^{\text {st }}$ Century. Oxford: Oxford University Press.

Thomas, A. (2000). Poverty and the 'End of Development', in Allen, T. \& Thomas, A. (eds.). Poverty and Development into the $21^{\text {st }}$ Century. Oxford: Oxford University Press.

White, C. (1987). State, Culture and Gender: Continuity and Change in Women's Position in Rural Vietnam, in Afsher, H. (ed.). Women, State and Ideology: Studies from Africa and Asia. London: Macmillan Press. https://doi.org/10.1007/978-1-349-18650-1_13

Woodhouse, P. (2000). Environmental Degradation and Sustainability, in Allen, T. \& Thomas, A. (eds.). Poverty and Development into the $21^{\text {st }}$ Century. Oxford: Oxford University Press.

World Bank. (1990). World Development Report 1990. Oxford: Oxford University Press.

World Bank. (1997). Rural Development: From Vision to Action. http://wbln0018.worldbank.org/ESSD/rdv/vta.nsf/Gweb/Strategy

World Bank. (2001). World Development Report 2000/2001: Attacking Poverty. Oxford: Oxford University Press.

\section{Copyrights}

Copyright for this article is retained by the author(s), with first publication rights granted to the journal.

This is an open-access article distributed under the terms and conditions of the Creative Commons Attribution license which permits unrestricted use, distribution, and reproduction in any medium, provided the original work is properly cited. 